\title{
NCK-Interacting Protein with SH3 Domain
}

National Cancer Institute

\section{Source}

National Cancer Institute. NCK-Interacting Protein with SH3 Domain. NCI Thesaurus. Code C97435.

NCK-interacting protein with $\mathrm{SH} 3$ domain $(722 \mathrm{aa}, \sim 79 \mathrm{kDa}$ ) is encoded by the human NCKIPSD gene. This protein plays a role in both stress fiber formation and signaling. 